\title{
A Rare Case of Broad Ligament Haematoma 24 Hours after Normal Vaginal Delivery
}

\author{
Murali $\mathbf{R}^{1}$, Hosni $\mathrm{MM}^{1^{*}}$ and Navaneetham $\mathrm{N}^{2}$ \\ ${ }^{1}$ Bradford Teaching Hospitals NHS foundation Trust, UK \\ ${ }^{2}$ George Eliot Hospitals NHS Trust, UK
}

*Corresponding author: Mohamed Hosni, Bradford Teaching Hospitals, Duckworth Lane, Bradford, West Yorkshire, BD9 6RJ, UK, Tel: 00(44)7919876444; E-mail: magedlap@yahoo.com

Rec date: Jun 25, 2014, Acc date: Jul 18, 2014, Pub date: Jul 21, 2014,

Copyright: (c) 2014 Murali R, et al. This is an open-access article distributed under the terms of the Creative Commons Attribution License, which permits unrestricted use, distribution, and reproduction in any medium, provided the original author and source are credited.

\begin{abstract}
We are reporting on a rare case of woman who developed broad ligament hematoma 24 hours after normal vaginal delivery. The patient had no history of congenital or acquired bleeding disorder, and the course of her pregnancy and labour were uneventful.
\end{abstract}

Keywords: Normal vaginal delivery; Broad ligament hematoma

\section{Case Report}

A 23-year-old woman G2P0, with one previous spontaneous miscarriage at 6 weeks, and BMI of 30.4 at booking. The patient was admitted to the labour ward at 41 weeks gestation with spontaneous onset of labour. The woman labour progressed very well. Her first stage of labour lasted for 13 hours and her second stage lasted for one hour. A living healthy male was delivered weighing 3000 grms followed by complete delivery of the placenta. Two hours later, the patient was transferred to postnatal ward as her immediate postpartum period was uneventful.

Twenty-four hours after delivery, the women started to feel unwell. She experienced severe perineal pain and inability to pass urine. Her physical examination revealed soft abdomen, with well contracted uterus. Her vulva looked oedematous with some bruising from the trauma of labour. There was no obvious haematoma in the vulva and the perineum. The vaginal examination could not be attempted due to the excruciating pain experienced by the patient. Her postpartum haemoglobin was $7.3 \mathrm{~g} / \mathrm{dl}$ dropping from $11.5 \mathrm{~g} / \mathrm{dl}$ antepartum. Two units blood were transfused and pain killers were prescribed. An ultrasound scan was requested urgently. The ultrasound scan revealed a right broad ligament haematoma measuring $9.76 \times 3.25 \times 6.9 \mathrm{~cm}$ (Figure 1).

A full coagulation screen [prothrombin time (PT), fibrinogen, activated partial thromboplastin time (APTT), thrombin time and DDimer], and thrombophilia screen [Protein C, Protein S, Antithrombin III, Factor V leiden mutation, prothrombin gene mutation(G-20210-A), and lupus anticoagulant] were done to exclude bleeding disorders. All her investigations came back negative.

Different options of management were discussed with the patient. However, conservative management was decided, as the patient was haemodynamically stable. The plan was to monitor patient's pulse, blood pressure, temperature, respiratory rate, oxygen saturation, and urine output (after inserting indwelling Foley's catheter) every 4 hours for the first 48 hours, then every 6 hours afterwards Intravenous prophylactic antibiotics (Co-amoxiclav 500/100 $\mathrm{mg}$ tds and metronidazole $500 \mathrm{mg}$ tds) were prescribed for 48 hours then switched to oral antibiotics for 5 days to complete a 7 day course of antibiotics. Pain killers, tranexamic acid 1 gram tds and mefenamic acid $500 \mathrm{mg}$ tds were also prescribed and given to the patient. The woman recovered well and was discharged home seven days later. Six weeks later, a repeated scan confirmed complete resolution of the hematoma.

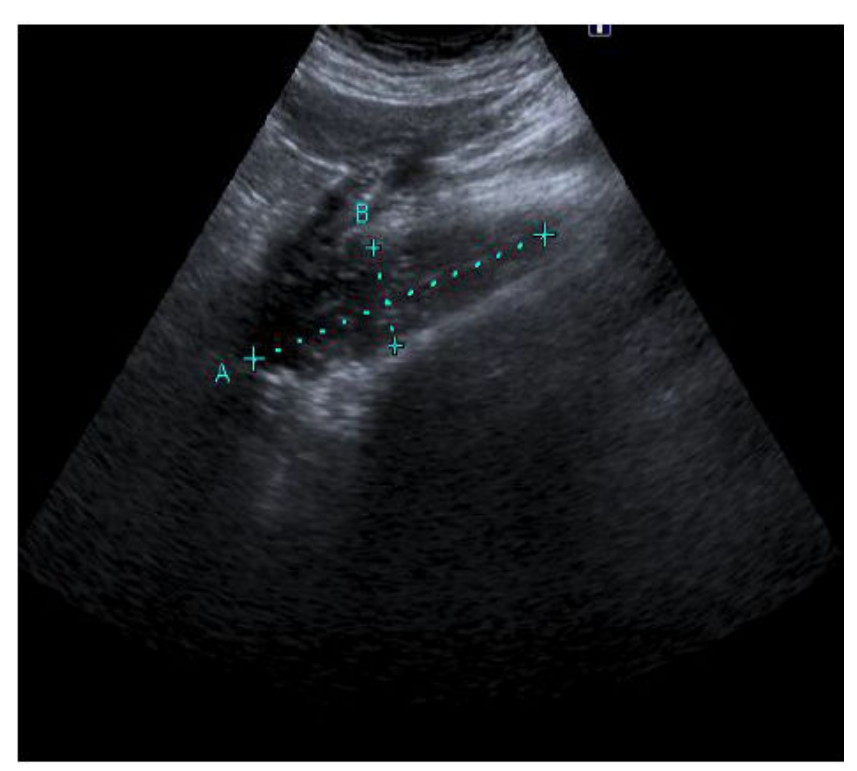

Figure 1: Broad Ligament Hematoma

\section{Discussion}

Broad ligament hematoma results from a tear in the upper vagina, cervix, or uterus that extends into uterine or vaginal arteries. It has incidence is $1: 20,000$. [1] It is very uncommon following normal vaginal delivery. It is most commonly associated with precipitate labour, caesarean section, trauma and instrumental vaginal deliveries. It can be life threatening, if the obstetricians are not aware of it. It can 
Citation: Murali R, Hosni MM, Navaneetham N (2014) A Rare Case of Broad Ligament Haematoma 24 Hours after Normal Vaginal Delivery. J

Page 2 of 2

be silent and not causing obvious vaginal bleeding [2]. Most patients present with persistent postpartum pelvic pain, back pain, fullness or pressure in the recto-anal area, or an urge to push within the first few hours after delivery. Women usually complain of headaches, dizziness and eventually may become hypotensive, with a sudden drop in haematocrit value. [3]

A high level of suspicion is warranted. Clinical symptoms can be quite vague. Ultrasound imaging can confirm the diagnosis. The role of pelvic MRI in the evaluation of such type of hematomas is still under investigations. MRI scan should be used to evaluate patients with persistent postpartum localized pelvic pain without clinical findings. [4]

Broad ligament hematoma can be treated either conservatively with close observation, or with surgical exploration under regional or general anaesthesia. Most broad ligament hematomas are self-limiting. Small non spreading ones may settle well without symptoms and without being diagnosed. Hysterectomy [5], internal iliac artery ligation or angiographic embolization [6] have been proposed as are surgical options depending upon patients' circumstances and their clinical presentation. In the presence of a haemodynamically stable woman and absence of congenital or acquired bleeding tendency, it seems amenable to adopt conservative management of such patients.

\section{References}

1. Saleem N, Ali HS, Irfan A, Afzal B (2009) Broad ligament hematoma following a vaginal delivery in primigravida. Pak J Med Sci 25: 683-685.

2. Edmonds, Dewhurst's Textbook of Obstetrics \& Gynecology. (6thedn), Blackwell Science, London.

3. Addo V, Kokroe FA, Reindorf RL (2009) Broad ligament hematoma following a Snake Bite. Ghana Med J 43: 181-182.

4. Jain KA, Olcott EW (1999) Magnetic resonance imaging of postpartum pelvic hematomas: early experience in diagnosis and treatment planning. Magn Reson Imaging 17: 973-977.

5. Maxwell C, Gawler D, Green J (1997) An unusual case of acute postpartum broad ligament haematoma. Australia NZ J Obstetrics \& Gynecology 37: 239-41.

6. Muthulakshmi B, Francis I, Magos A, Roy M, Watkinson A (2003) Broad ligament haematoma after a normal delivery. Journal of Obstetrics \& Gynecology 23: 669-670. 